\title{
Mainstreaming climate change adaptation into sectoral policies in Nepal: A review
}

\author{
Pashupati Nepal \\ Central Department of Geography, Tribhuvan University, Kathmandu, Nepal \\ Email: nepalpashupati@yahoo.com
}

\begin{abstract}
Nepalese people have experienced climate variability for a long time and the mitigation and adaptation responses they have made to reduce the effect of climate variability are not new phenomena for Nepal. However, mainstreaming climate change issues into sectoral policies from the government can be seen as recent activities in Nepal. Nepal has contributed negligible amount of emissions of Greenhouse Gases (GHGs) of global greenhouse gas, it is the fourth most vulnerable country in the world. In this context, this paper aims to review climate change adaptation policies in terms of sectoral integration. This paper has adopted text-mining method for information retrieval and knowledge mining and followed step-by-step approach to undertake review of policies. It concludes that National Adaptation Programme of Action (NAPA) in 2010 can be a milestone in sectoral adaptation of climate change issue largely because it has provided the national framework for sectoral adaptation to climate change. However, NAPA ignores the importance of structural and institutional reforms needed for mainstreaming climate change adaptation into sectoral agencies. Climate change Policy, 2011, Local Adaptation Plan of Action (LAPA) 2011, Constitution of Nepal, 2015, Local Government Operation Act (LGOA) 2017, Disaster Risk Reduction and Management Act, 2017 and National REDD+Strategy, 2018 are other prominent legislative and policy frameworks that have significant contribution in sectoral integration of climate change adaptation issues. However, lack of climate change act in order to implement fully these policies into practice for its implementation can be a major obstacle to achieve the goal. In this context, strong legislative foundation with effective institutional mechanism among different sectors will be very crucial to capture the spirit of new Federal Constitution of Nepal.
\end{abstract}

DOI: http://dx.doi.org/10.3126/gjn.v12i1.23412 
Keywords: climate, adaptation policies, mainstreaming, legislation, policies/ plans

\section{Introduction}

Mainstreaming climate change is the iterative process that integrates climate change adaptation into policy making at national, sectoral, and subnational levels (UNDPUNEP, 2011; Regmi and Shrestha, 2018; Regmi and Bhandari, 2013). It focuses on integrating climate change adaptation into the policy formulation process such as national development plans or sectoral initiatives based on country-specific evidence. The integration of climate change issue into sectoral policies have got top priority among the international and national scholars particularly after the Fifth Assessment Report of the Intergovernmental Panel on Climate Change (2014) which confirmed that each of the last three decades has been successively warmer at the Earth's surface than any preceding decade since 1850 . The period from 1983 to 2012 was likely the warmest 30-year period of the last 1400 years in the Northern Hemisphere (IPCC, 2014). The growing likelihood of a more than $2{ }^{\circ} \mathrm{C}$ warmer world requires better adaptation policy (Di Gregorio et al., 2017) to reduce the current and future effects of climate change. Moreover, IPCC (2014) noted that the longer we wait to take action, the more it will cost and the greater the technological, economic, social and institutional challenges we will face.

The issue of adapting to climate change and variability is not new because people and communities have lived with climate variability for a long time. They have developed management decisions to cope with it (Berrang-Ford, James, Ford, and Peterson, 2011). However, the adaptation strategies adopted may not be sufficient to address the issue of climate change (Levine, Ludi and Jones, 2011). There are two ways to response to climate change; one is adaptation and other being mitigation (IPCC, 2001a; UNISDR, UNDP, 2012). Mitigation is an anthropogenic intervention to reduce the sources or enhance the sinks of greenhouse gases whereas, adaptation is an adjustment in natural or human systems in response to actual or expected climatic stimuli or their effects, which moderates harm or exploits beneficial opportunities (IPCC, 2001a). Mitigation and adaptation represent two complementary aspects of climate change, which need to be addressed through a holistic approach (Dewulf, 2013). The urgency associated with adaptation is how it can be facilitated, supported, planned and sustained (Nkiaka and Lovett, 2018). It is widely acknowledged that policies need to provide a supportive environment in planning and executing adaptation interventions to climate change (Berman et al., 2015; Zougmoré et al., 2016) because adaptation is also the idea of incorporating future climate risk into policy making and practices (MoEST, 2012). 
The trend analysis of maximum temperature in Nepal carried out by Shrestha, Wake, Dibb, and Mayewski (1999) and Baidya, Shrestha and Sheikh (2008) found that the average annual warming between 1971 and 1994 was $0.06^{\circ} \mathrm{C} /$ year. The warming in the maximum temperature is found to be more pronounced in the high altitude regions. The General Circulation Models scenario shows that the mean annual temperature to increase by an average of $1.2^{\circ} \mathrm{C}$ by $2030,1.7^{\circ} \mathrm{C}$ by 2050 and $3^{\circ} \mathrm{C}$ by 2100 compared to a pre-2000 baseline (MoE, 2010). The days and nights are likely to be become warmer in the days to come than in the past (MoE, 2010). Nepal has contributed negligible amount of emissions of Greenhouse Gases (GHGs) of $0.027 \%$ of global greenhouse gas emission (MoPE, 2016) but is the fourth most vulnerable country in the world due to the effects of climate change (MoSTE, 2015) due to increasing temperature and change in precipitation patterns in different sectors including agriculture, forest, water resources and disaster (MoPE, 2016). The Economic Impact Assessment of Climate Change in Key Sectors (2013) has estimated that the current climate variability and extreme events has costs equivalent to 1.5 to 2 percent of current GDP (approximately $\$ 270$ to 360 million a year) and much higher in extreme years (MoSTE, 2013). The emerging climate status of Nepal demands integration of climate change adaptation into various sectoral policies/plans and programs so that people can adapt to the changing situation (NPC, 2011).

In response to the climate change, Nepal has made several commitments at the International and Regional level. Nepal signed the UN Convention Framework on Climate Change (UNFCCC) on 12 June 1992 during the Rio Earth Summit and ratified it on 2 May 1994. This Convention came into force in Nepal on 31 July 1994 (MoPE, 2004). The Convention is complemented by the Kyoto Protocol and entered into force on December 2005 under the UNFCCC (MoEST, 2012). On 12 December, 2015, Conference of Parties (COP-supreme body of the UNFCCC) to the UNFCCC agreed to a historic climate change agreement called the "Paris Agreement" (PA). Nepal as a party to the convention has signed the agreement on April 22, 2016 in New York and ratified international treaty by the parliament and entered into force on 4 November, 2016. Paris Agreement (COP 21, 2016) recognized adaptation as a global challenge, and focused to promote national actions and adaptation planning including NAP formulation and implementation, and strengthening institutional arrangement. As a party to the UNFCCC, Nepal has participated in the COP 22 which was held in Bab Ighli, Marrakech, Morocco from 7 to 18 November 2016 (MoPE, 2016). At regional level, South Asian Association for Regional Cooperation (SAARC) Environment Minister's Dhaka Declaration on Climate Change (Dhaka, 3 July 2008) agreed for adaptation of climate change to protect the lives and livelihood of people for food, water and energy securities (SAARC, 2008). In the same line, Thimpu Statement on Climate Change (Thimpu, 28-29 April 2010) 
agreed to establish an Inter-governmental Expert Group on Climate Change to develop clear policy direction and guidance for regional cooperation and establish institutional linkages among national institutions for climate change issues (SAARC, 2010).

In response to initiatives in regional and international level, Nepal is making robust efforts to address climate change through policy formulation, institutional arrangements and strengthening, program development and implementation (MoPE, 2016). In 1992, with the birth of an international treaty, the United Nations Framework Convention on Climate Change (UNFCCC), national governments had urged to put in place manifold strategies to limit the average global temperature increase and curb the unavoidable impacts (UN, 1992). In order to respond the climate change impacts, many governments have developed adaptation policies and plans at various levels and integrated into broader development plans and agenda (IPCC, 2014). Nepal has also developed and submitted National Adaptation Programme of Action (NAPA) to the United Nations Framework Convention on Climate Change (UNFCCC) in 2010 with its national adaptation priorities to deal with such climatic risks and hazards (MoE, 2010). Furthermore, the Government of Nepal (GoN) has endorsed national climate change policy and National Framework of Local Adaptation Plan of Action (LAPA) in 2011 to implement the NAPA priorities (Regmi and Karki, 2010; GoN 2011; Regmi and Bhandari, 2012; Regmi, Star and Filho, 2014). Realizing the need to move towards low carbon climate resilient development, Nepal has also endorsed National REDD+ strategy in 2018 to help regulate REDD+ initiatives in Nepal (MoFE, 2018).

Only a few research works elicit how policy, legislation and institutional structure influences adaptation strategies in the context of climate change in Nepal. Much of the previous research works are concentrated either in adaptation measures or in policy intervention. For example, Adger, Hug, brown, Conway and Hulme (2003); Huq, Reid, Konate, Rahman, Sokona and Crick (2004); Ford and Pearce, (2010) have only highlighted the essentiality of adaptation measures to reduce the effect of climate change. Likewise, Osman-Elasha et al (2008), Saito (2013), Regmi and Star (2015) and Agrawala, Raksakulthai, van Aalst, Larsen, Smith \& Reynolds (2003), Dessai and Hulme (2004), Vij, Moors, Ahmad, Uzzaman, Bhadwal, Biesbroek (2017) Pant \& Gautam. (2013) and Ojha, Ghimire, Pain, Nightingale, Khatri and Dhungana (2016) only looked into the policy dimensions during mainstreaming climate change adaptation policies into various sectors. Agrawal (2010) and Bisaro, Roggero and VillamayorTomas (2018) have focused on institutional aspect of climate change adaptation. In their respective studies, Maharjan and Maharjan (2017), Dhungana, Pain, Khatri, Gurung and Ojha (2013) and Mubaya and Mafongoya (2017) have highlighted the crucial role of climate policies and institutions in effective adaptation to climate change in Nepal. 
Besides policy and institutional arrangements, the legislative framework is also an important element in mainstreaming climate change adaptation into sectoral policies. Therefore, this paper fills in the gaps in terms of understanding the policy, legislative frameworks and institutional adequacy in mainstreaming climate change adaptation into sectoral policies.

\section{Methodological framework}

This paper is based on desk review of documents related to climate change adaptation policies formulated by different sectors available in English and Nepali languages. The text-mining method has been used for the information retrieval and knowledge mining. It analyses the text according to text characters or sentence structure (Scherf, Epple and Werner, 2005; Regmi and Shrestha, 2018) in order to reduce the time taken to identify, categorize, and summarize relevant literature (Ananiadou, Rea, Okazaki and Thomas, 2009; Thomas and Ananiadou, 2011).

While reviewing the mainstreaming of climate change adaptation policies, this paper focuses on four main sectors, such as agriculture, forest, water resource and disaster and has followed step by step approach to undertake review of their policies. At first, soft copy of policy documents was collected from the systematic web search (Viz, Biesbroek, Groot and Termeer, 2018) of various Ministries and Departments and Nepal Law Commission. The hardcopy of the policy documents was collected from the concerned sectoral ministries such as the Ministry of Agriculture, Ministry of Forest and Environment, Ministry of Energy, Water Resources and Irrigation and Ministry of Home Affairs. In addition, as the Ministry of Forest and Environment undertakes the key responsibility to formulate and implement climate change policies, its all climate related documents so far available have been reviewed. Furthermore, the documents both in soft copy and hardcopy related to climate change from the National Planning Commission, the apex body of the policy guidance in Nepal, were also collected and reviewed. Secondly, the documents related to climate change policies have been grouped into three broad categories, such as regulatory frameworks, policies/plans and programs, and institutional structures (roles and linkages). Thirdly, the documents related to regulatory frameworks and policies/plans have been analyzed in terms of mitigation and adaptation responses. Fourthly, the documents on climate change adaptation policies have been analyzed by major four potential impact sectors of climate change, such as agriculture, water resources, forest and disaster. Additionally, adaptation policies were also analyzed in terms of vertical policy coherence i.e. "coherence between different levels of government" (Geerlings and Stead 2003), such as national/federal, provincial and local level. Finally, based on the content analysis of policy documents, gaps and 
constraints in mainstreaming climate change adaptation into sectoral policies were identified (Figure 1).



Figure 1: Methodological framework

\section{Results and discussion}

\section{Mainstreaming climate change adaptation into national and sectoral legislative frameworks}

This section assesses the climate change adaptation issues based on the existing national and sectoral legal documents. The Water Resource Act (1992) emphasizes to minimize adverse effect on environment by way of soil erosion, flood, and landslide or similar other causes (HMG, 1992). The Forest Act, 1993 aims to manage forest resources in Nepal from the perspective of disaster management (HMG, 1993). The Environment Protection Act, 1996 and its Rules, 1997 has made provision of Environmental Impact Assessment (EIA) before starting development activities (HMG, 1997). The Constitution 
of Nepal, 2015 provides the right regarding clean environment stating 'each person shall have the right to live in a healthy and clean environment'. It has mandated different responsibilities to different tiers of the government regarding the water resource management. For example, the federal government is mandated to conserve water resources and develop policy and standards for multi water uses, while the provincial governments are mandated to manage water resources within their provincial jurisdiction and the local governments are mandated to manage the drinking water and watershed management and protection of watersheds, wildlife, mines and minerals under their jurisdictions. The constitution has also mandated the provinces to pursue the policies of making a sustainable use of biodiversity through the conservation and management of forests, minimize or stop negative effects on environment and minimize the risks of natural disasters (GoN, 2015). The Disaster Risk Reduction and Management Act promulgated in 2017 has categorized the disasters for the first time into two groups: natural and human induced. It defines the climate change related disaster as natural disaster. It provides detailed action plan for different levels of government to execute the disaster management plan (MoLJPA, 2017). The Local Government Operation Act (LGOA) 2017 recognizes that local people and local bodies are the most appropriate points of entry to meet the climate change adaptation needs at the local level. It also authorizes to undertake carbon reduction and environment friendly development with respect to climate change by local bodies (MoLJPA, 2017).

\section{Mainstreaming of climate change adaptation into sectoral policies/plans and strategies}

Different sectoral policies/plans and strategies are found to be designed for the mainstreaming climate change adaptation into sectoral policies. The Ninth Plan (19972002) focused on the application of new information technology for preventive and protective measures at the time of natural disasters such as flood (NPC, 1997). The National Conservation Strategy (NCS), 1998 has adopted the objectives to ensure the sustainable use of land and renewable resources, preserve the biological diversity, and; maintain essential ecosystems (NPC/IUCN, 2013). The Nepal Biodiversity Strategy, 2002 sets objectives for the protection of biological diversity in Nepal and identifies Government policy on natural resources and their diversity. This strategy highlights climate-related risks, such as flooding, environmental degradation and pollution, and soil erosion as the root causes of threats to biodiversity (MoFSC, 2002). For the first time, disaster management issue was included in the Tenth Plan (2002-2007) formulated by the National Planning Commission of Nepal. It emphasized on the irrigation and water induced disaster control (NPC, 2002). The World Summit on Sustainable 
Development (WSSD), 2002 identified the linkage between climatic circumstances and land degradation, erosion and landslides (UN, 2002).

The National Water Resources Strategy, 2002 recognizes climate variability and its potential impacts on the country's water resources. It recognizes water-induced disaster as one of the main types of disaster in Nepal with an aim to manage and mitigate these events. In regard to the climate change adaptation it identifies specific activities, including risk and vulnerability mapping, floodplain action plans, integrated water management, public education, and the establishment of a Himalayan climate change study centre (WECS, 2003). The National Agriculture Policy, 2004 has emphasized on conserving, promoting and utilizing natural resources, environment and bio-diversity (MoAC, 2004). The National Water Plan, 2005 stressed on institutional capabilities and measures for managing water-induced disasters and mitigation of their adverse effects. It also focuses on the requirement for research and studies to better understand climateinduced changes and their impact on the environment (WECS, 2005). The Water Induced Disaster Management Policy-2006 highlighted to mitigate water induced disasters and reduce loss of lives and property and to enhance institutional strengthening (DWIDM, 2006). Similarly, the Three Year Interim Plan (2007/08-2009/10) has devoted a separate chapter on natural disaster management in its planning document. The interim plan emphasizes on policy formulation, strengthening institutional mechanism, Early warning system (EWS), coordinated approach for Disaster Risk Reduction (DRR) and linking disaster management with climate change (NPC, 2007).

Climate change was recognized as a serious risk by the National Strategy for Disaster Risk Management in Nepal (2009) and climate risk management and adaptation to climate variability were taken as significant priorities (MoHA, 2009). The National Adaptation Programme of Action (NAPA), 2010 is the first comprehensive government response to climate change which identified nine urgent and immediate climate change adaptation priority programmes related to six thematic sectors (agriculture, forest biodiversity, water resources, health, infrastructure, and disaster). It also specified a coordination mechanism and implementation modality for climate change adaptation programmes (MoE, 2010). The Twelfth Three Year Plan (2010/11-2012/13) for the first time, devoted separate chapter of environment and climate change (Chapter 6, section 6.9) in planning document of Nepal. It focuses on green development, making development activities climate-friendly and resilient, mitigating the negative impacts of climate change and promoting adaptation (NPC, 2010). The National Climate Change Policy, 2011 aims to improve livelihoods by mitigating and adapting to the adverse impacts of climate change, adopting a low-carbon emissions socioeconomic development path. It has made 
provision of allocating at least 80 percent of the total budget from Climate Change Fund directly to programme implementation at the community level (MoPE, 2011). Though there are a few CDM projects in operation, it is not finalized yet (Lamsal, Chaudhary and Bhandari, 2014). The Local Adaptation Plans for Action (LAPA), 2011 provided operational instrument to implement NAPA prioritized adaptation actions. LAPA aims to integrate climate adaptation activities into local and national development planning processes, and to make development more climate-resilient (MoE, 2011). The Climate Resilient Planning Tool, 2011 formulated by National Planning Commission provided a climate resilience framework to guide the country in implementing development plans. It has recommended methods, tools and approaches for guiding climate-resilient planning (NPC, 2011). The Climate Change Adaptation and Disaster Risk Management in Agriculture: Priority Framework for Action 2011-2020 provides a road map for the MOAC to shift its approach from reactive emergency response to proactive climate adaptation and climate risk management in the agriculture sector (MoAC, 2011). In order to work on disaster risk management, the Local Disaster Risk Management Planning Guidelines (LDRMP), 2012 was designed (MoFALD, 2012). The Thirteenth Periodic Plan (2013/14-2015/16) has adopted the green development approach to mitigate the impacts of climate change. It has considered environment and climate change a crosscutting issue. It has focused on implementation of NAPA through LAPA at the local level (NPC, 2013). The Irrigation Policy, 2014 aims to provide irrigation facility round the year for the achievement of the objectives related to the climate change, through effective management of existing water resources and strengthening institutional capacity (MoIr, 2014). The Sustainable Development Goals (2015-2030) committed to "urgent action to combat climate change and its impacts" through strengthening resilience and adaptive capacity to climate-related hazards and natural disasters, integrating climate change measures into national policies, strategies and planning; and improving institutional capacity on climate change mitigation, adaptation, impact reduction and early warning (NPC, 2015). The Water Induced Disaster Management Policy, 2015 recognizes climate change as one of the causes for water induced disasters. It also focuses on disaster prevention programmes to make them climate resilient and environment friendly (MoIr/ GoN (2015). The Forest Policy, 2015 has taken strategy for reduction of negative impact of climate change and adoption of adaptation strategies (MoFSC, 2015). The National Adaptation Plans (NAPs) 2015 aims to reduce vulnerability to the impacts of climate change by building adaptive capacity and resilience; and integrate of climate change adaptation into existing policies/plans and programmes within all relevant sectors and at different levels (GoN/MoPE, 2017). The National Land Use Policy, 2015 has focused to protect the government land by forestation and plantation programmes on degraded lands (MoLRM, 2015). The Agriculture Development Strategy (2015-2035) targeted to 
increase the volume of food production through higher productivity and sustainable use of natural resources. It focuses on improved preparedness and response to emergencies, and climate smart agricultural practices (ADB, 2013). Current Fourteenth Periodic Plan (2016/17-2018/19) focuses to achieve development goals through implementing adaptation measures to reduce the impact of climate change. The plan has emphasized to reform policies and strengthen legal frameworks and institutional settings. It has adopted green development strategy to reduce the impact of climate change (NPC, 2016). The Forestry Sector Strategy, 2016-2025 identifies climate change mitigation and resilience as one of the eight strategic pillars. It also aims to protect forest, biodiversity, plants resources, wildlife, watersheds and other ecosystems and sustainably managed, and climate resilient opportunities (MoFC, 2018). The National REDD+ Strategy, 2018 aims to reduce carbon emissions, enhance carbon stocks and ecosystem resilience through mitigation and adaptation approaches by minimizing the causes and effects of the drivers of deforestation and forest degradation, and promoting sustainable forest management across ecological regions (MoFE, 2018). The National Ramsar Strategy and Action Plan, Nepal (2018-2024) aims to engage federal, state and local stakeholder and capacitate them for the wetlands and Ramsar sites conservation (MoFE, 2018).

Table 1 summarizes the responses of the climate change policies in terms of mitigation and adaptation and their integration by major four potential impact sectors such as, agriculture, water resources, forest and disaster. The table also summarizes the adaptation policies by level of government, such as federal, provincial and local. It is seen in the table that the fact regulatory frameworks being formulated during the 1990s have concentrated on the environmental conservation, but not dealt with the responses to climate change while the legislations promulgated recently have spelled out about responses of climate change by different sectors. For instance, NAPA, 2010 is the first comprehensive government response to climate change adaptation for different sectors and provides institutional mechanism at national level for climate change adaptation programmes. Similarly, LAPA, 2011 has also provided operational instrument to implement NAPA prioritized adaptation actions for different sectors at the local level. National Climate Change Policy, 2011 is an important policy document which has for the first time addressed climate change mitigation and adaptation issues separately in Nepal and provided institutional mechanism for implementing climate change issues by different sectors. Various periodic plans particularly from the Ninth Plan (19972002) to current Fourteenth Plan (2016/17-2018/19) have addressed the climate change adaptation issues directly or indirectly. 
Table 1: Climate change policies with its responses, potential impact areas and level of governance

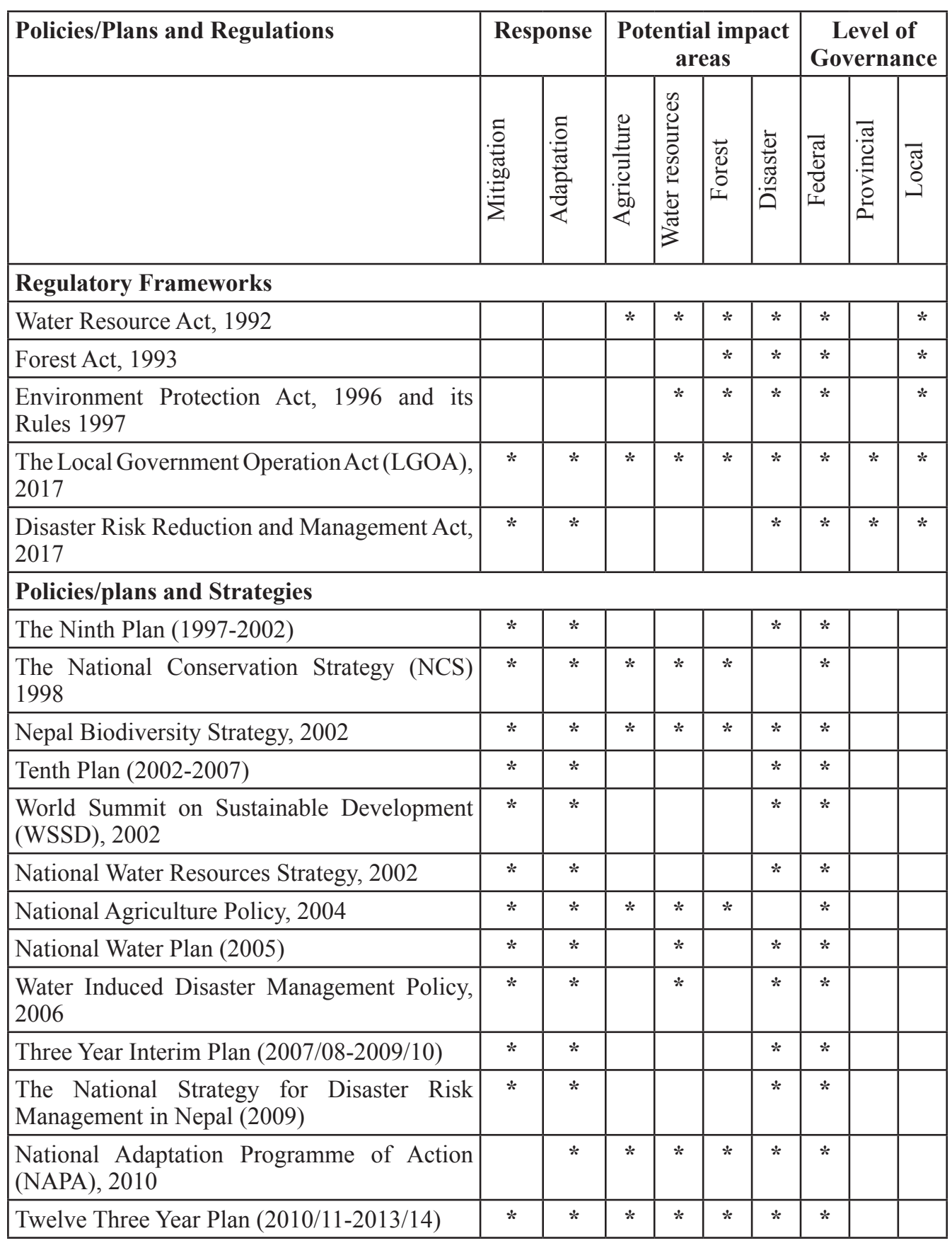




\begin{tabular}{|l|c|c|c|c|c|c|c|c|c|}
\hline Climate Change Policy ,2011 & $*$ & $*$ & $*$ & $*$ & $*$ & $*$ & $*$ & & \\
\hline $\begin{array}{l}\text { Local Adaptation Plan for Action (LAPA) } \\
2011\end{array}$ & $*$ & $*$ & $*$ & $*$ & $*$ & $*$ & & $*$ \\
\hline Climate Resilient Planning Tool, 2011 & $*$ & $*$ & $*$ & $*$ & $*$ & $*$ & $*$ & & \\
\hline $\begin{array}{l}\text { Climate Change Adaptation and Disaster } \\
\text { Risk Management in Agriculture: Priority } \\
\text { Framework for Action 2011-2020 }\end{array}$ & & $*$ & $*$ & & & & $*$ & & \\
\hline $\begin{array}{l}\text { Local Disaster Risk Management Planning } \\
\text { Guidelines (LDRMP), 2012 }\end{array}$ & & $*$ & & & & $*$ & & & $*$ \\
\hline Thirteenth Plan (2013/14-2015/16) & $*$ & $*$ & $*$ & $*$ & $*$ & $*$ & & & \\
\hline Irrigation Policy, 2014 & & $*$ & $*$ & $*$ & $*$ & $*$ & $*$ & & \\
\hline Sustainable Development Goals (2015-2030) & $*$ & $*$ & & & & $*$ & $*$ & & \\
\hline $\begin{array}{l}\text { Water Induced Disaster Management Policy, } \\
\text { 2015 }\end{array}$ & $*$ & & & & $*$ & $*$ & & \\
\hline Forest Policy, 2015 & $*$ & $*$ & & & & $*$ & $*$ & & \\
\hline National Adaptation Plans (NAPs) 2015 & & $*$ & $*$ & $*$ & $*$ & $*$ & $*$ & & \\
\hline National Land Use Policy, 2015 & $*$ & & $*$ & & $*$ & & $*$ & & \\
\hline $\begin{array}{l}\text { Agriculture Development Strategy (2015- } \\
\text { 2035) }\end{array}$ & & $*$ & $*$ & & & & $*$ & & \\
\hline Fourteenth Periodic Plan (2016/17-2018/19) & $*$ & $*$ & $*$ & $*$ & $*$ & $*$ & $*$ & & \\
\hline Forestry Sector Strategy (FSS), (2016-2025) & $*$ & $*$ & $*$ & $*$ & $*$ & $*$ & $*$ & & \\
\hline National REDD+ Strategy & $*$ & $*$ & & & & $*$ & $*$ & & \\
\hline $\begin{array}{l}\text { National Ramsar Strategy and Action Plan, } \\
\text { Nepal (2018-2024) }\end{array}$ & $*$ & $*$ & & $*$ & $*$ & & $*$ & $*$ & $*$ \\
\hline
\end{tabular}

\section{Institutional structure to climate change}

In order to address the climate change issue with better institutions and coordination, national coordination mechanisms and institutional arrangements has been created by the GoN (Figure 2). GoN has formed the Climate Change Council (CCC) in 2009 (MoE, 2011). The CCC is a 25-member high-level coordination body chaired by the Prime Minister, and includes 11 ministers and eight technical experts nominated by the GoN, with MoFE (previously MoSTE) functioning as the Secretariat of the Council. The task of CCC is to provide high-level policy and strategic vision, to coordinate financial and technical support to climate change-related programs and projects. To coordinate climate change activities and implement collaborative programs, a Multi-stakeholder Climate Change Initiatives Coordination Committee (MCCICC) was formed in 2009, to promote functional level coordination amongst the stakeholders and streamline climate change activities. 


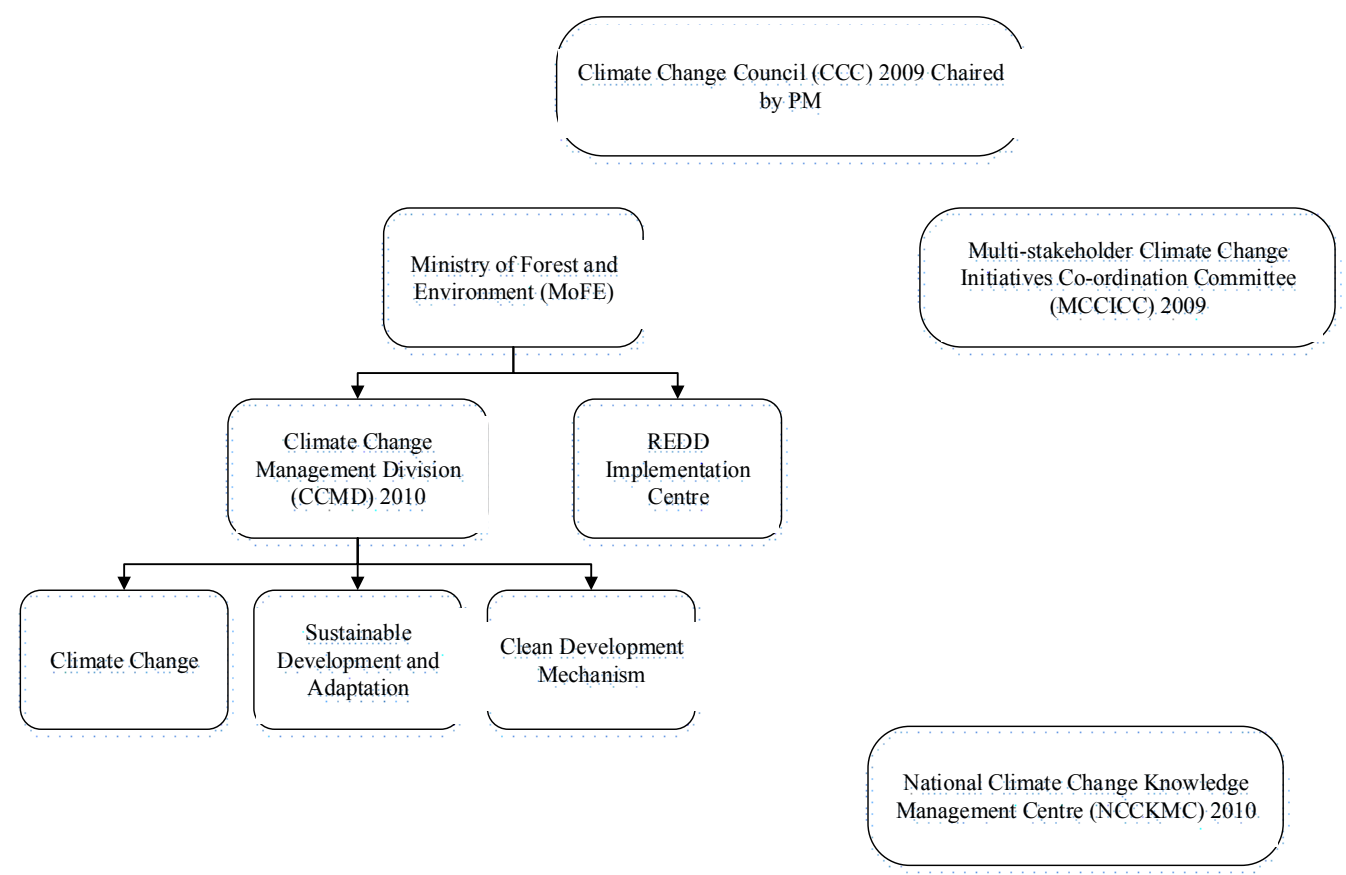

Figure 2: Institutions supporting implementation of climate change policies in Nepal Notes: REDD = Reducing Emissions from Deforestation and Forest Degradation.

Source: Fisher and Slaney (2013).

Six thematic working groups (TWGs) initially established during the development of the NAPA have been institutionalized as a part of the climate governance structure. They are composed of experts representing relevant subsectors. The TWGs are led by a different ministry and cover different themes - agriculture and food security, forests and biodiversity, water resources and energy, climate-induced disasters, public health, and urban settlements and infrastructure. Each TWG has around 15 members, comprising representatives from government agencies, NGOs, academic institutions, and relevant UN agencies (MoE, 2010). These TWGs have the potential to play a key role in future cross-sectoral integration and coordination of climate change adaptation initiatives (Ayers, Kaur, \& Anderson, 2011). Established in 2010, the National Climate Change and Knowledge Management Centre (NCCKMC) is a collaborative effort of the Nepal Academy of Science and Technology (NAST) and MoSTE (now MoFE) under the NAPA project. The NCCKMC is based in NAST with the mission to serve as a dedicated institutional arrangement for managing climate change knowledge in Nepal, and the goal of providing a platform for coordinating and facilitating the regular generation, 
management, exchange, and dissemination of climate-related knowledge and capacity development services to a multi-stakeholder climate change community of practice in Nepal (Fisher and Slaney, 2013). Likewise, REDD Cell in 2009 (renamed as REDD Implementation Centre in 2014) were established. Focal persons for climate change in different Ministries were determined.

Several ministries are key in implementing climate change-relevant programs, and MoFE (previously MoSTE) has the sole responsibility to coordinate all climate change-related projects. This ministry has the national mandate to formulate, implement, monitor, and evaluate policies, plans, and programs on environment and climate change. MoFE is also the National Focal Point for the UNFCCC.

\section{Gaps and constraints}

Though several sectoral ministries have a role to implement the climate change adaptation activities, the MoFE is officially assigned to undertake the task of coordination for all climate change-related activities. This ministry has the national mandate to formulate, implement, monitor, and evaluate climate change policies, plans, and programs. As a functional institution, the responsibility of implementing NAPA and climate change policy goes to the MoFE which was previously the responsibility of MoSTE (MoE, 2010; MoSTE, 2015). However, MoFE requires capacities and confidence to coordinate among ministries (Regmi and Bhandari, 2012).

The Government of Nepal realized an urgency to respond the effects of climate change for the first time through institutional mechanism and formed a high-level coordination body viz Climate Change Council (CCC) under the Chairmanship of the Prime Minister in 2009. Its formation, however, does not seem to percolate into the implementing level. Multi-stakeholder Climate Change Initiatives Coordination Committee (MCCICC) was formed to undertake coordination amongst the stakeholders at the central as well as local levels. However, there is a lack of coherence in defining the role of the CCC and MCCICC in sectoral policies (Ranabhat, Ghate, Bhatta, Agrawal, and Tankha, 2018). Policy requires a legislative framework for its implementation. For example, Article 12 of the Nepal Climate Change Policy, 2011 has made a provision of formulating new laws and necessary revisions of existing ones, as required for the effective implementation of climate change related conventions and protocols (Lamsal, Chaudhary and Bhandari, 2014). Currently, the policy does not have supporting legislation to implement it. In this context, climate change policy describes the goals and objectives in detail, but fails to 
provide clear identification of the main agents for implementation (Lamsal, Chaudhary, and Bhandari, 2014). NAPA, 2010 identified urgent climate change adaptation priority programmes for different sectors. However, it ignores the importance of structural and institutional reforms needed for mainstreaming climate change adaptation into sectoral agencies. It is also silent about the capacity building of the local bodies required during implementation of adaptation activities (Meyer-Ohlendorf 2009; Satterthwaite et al., 2007). Since the Constitution of Nepal, 2015 and Local Government Operation Act, 2017 have given sole responsibilities to the local bodies (Gaunpalika/Nagarpalika) to undertake climate change adaptation activities, strengthening capacity building of the local bodies for planning and implementation is crucial. Similarly, the institutions, organizations, roles and responsibilities, identified by the NAPA are not acknowledged by the other policies such as, Climate Change Policy 2011, National Biodiversity Strategy and Action Plan 2014-2020, Forest Policy 2015, and Forest Sector Strategy 2016 for implementing climate change adaptation activities (Ranabhat, Ghate, Bhatta, Agrawal, and Tankha, 2018). This can result institutional incoherence among the ministries and departments. The absence of clear and strong institutional set-up for implementation of climate change adaptation activities is the major constraint for its practical implementation (Ampaire et al., 2017). Analyzing the forest sector policies in Nepal, Ranabhat, Ghate, Bhatta, Agrawal, and Tankha (2018) also highlighted that forest policies are more consistent on adaptation measures but are less coherent on implementation. At the time of climate change policy formulation, MoFE has the key role but the implementation lie with local government. It is not clear whether local level government such as municipalities and rural municipalities (Gaunpalika/Nagarpalika) actually had an obligation to implement these provisions or they are established under the Local Government Operation Act (2017) makes them independent from this obligation.

One of the major problems with most of the policies and programs in Nepal is the lack or inadequacy of proper data base. If there are data bases, they are outdated and irrelevant. There is a link between weak databases and policies and programs formulation that results in poor performances. On top of them, no separate units of database in each sectoral ministry or department have been set up so far.

\section{Conclusion}

This paper primarily aims in identifying the extent of mainstreaming climate change adaptation policies into the water resource, agriculture, forests and disaster sectors in Nepal. During the systematic review of policy documents published by the Government, 
text-mining method was adopted. Review of the policy documents reveal that through different legislations, national policies/plans and institutional arrangements, Nepal has been made a significant progress in mainstreaming climate change adaptation issues into different sectoral policies. NAPA, 2010 is the first comprehensive climate change adaptation document formulated from the government as response of adaptation measures to different sectors. It has also provided institutional mechanism at national level for the implementation of these measures. LAPA, 2011 has provided the adaptation plan for local level and integrated climate adaptation activities into local level. National Climate Change Policy, 2011 is an important policy document, which has for the first time addressed climate change mitigation and adaptation issues separately in Nepal. To coordinate abrupt climate changes and implement collaborative programs, a Multistakeholder Climate Change Initiatives Coordination Committee was formed in 2009. However, cross-sectoral coordination and simultaneous structure at the local level is still lacking. Until now, the sole responsibilities of implementing climate change policies goes to the Ministry of Forest and Environment (MoFE) leaving other ministries as passive partners. This can create incoherence between and among the ministries and departments. The sectoral policies formulated by the government have inadequate focus in mainstreaming climate change adaptation issues. Low awareness among the government officials and inadequate political commitment and priority of the nation can be the reasons for inadequate sectoral integration of climate change adaptation in their policy design. The policy formulation and institutional set-up alone does not give much expected out-put unless they are complemented by legislation. Until now, there is not a single legal document in Nepal that exclusively addresses the climate change issue. Therefore, promulgation of umbrella act and revision of The National Climate Change Policy, 2011 can resolve the problems of climate change in the spirit of the New Federal Constitution of Nepal, 2015.

\section{References}

ADB (2013). Nepal: Agricultural Development Strategy — Final Report. Technical Assistance Consultant's Report. Prepared by PPTA Consultants Kathmandu, Nepal for Government of Nepal. http://www.adb.org/sites/default/files/projectdocument/78233/434 47- 022-nep-tacr-01.pdf

Adger, W.N., Huq, S., Brown, K., Conway, D., Hulme, M. (2003). Adaptation to climate change in the developing world. Progress in Development Studies, 3 (3):179195. 
Agrawal, A. (2010). Local institutions and adaptation to climate change. In R. Mearns and A. Norton (editors), Social dimensions of climate: Equity and vulnerability in a warming world (Pp 173-197). Washington, D.C., USA: World Bank.

Agrawala, S., Raksakulthai, V., van Aalst, M., Larsen, P., Smith, J. \& Reynolds, J. 2003. Development and climate change in Nepal: Focus on water resources and hydropower. Paris: Organisation for Economic Cooperation and Development (OECD).

Ampaire, E. L., Jassogne, L., Providence, H., Acosta, M., Twyman, J., Winowiecki, L. and van Asten, P. (2017). Institutional challenges to climate change adaptation: A case study on policy action gaps in Uganda. Environmental Science and Policy, 75: 81-90. Available at www.elsevier.com/locate/envsci.

Ananiadou, S., Rea, B., Okazaki, N., Procter, R. \& Thomas, J. (2009). Supporting systematic reviews using text mining. Social Science Computer Review. 27(4), 509-523.

Ayers, J., Kaur, N., \& Anderson, S. (2011). Negotiating climate resilience in Nepal. IDS Bulletin, 42(3), 70-79. Retrieved from https:/opendocs.ids.ac.uk/opendocs/ handle/123456789/7599

Baidya, S. K., Shrestha, M. L., and Sheikh, M. M. (2008). Trends in daily climatic extremes of temperature and precipitation in Nepal. Journal of Hydrology and Meteorology, 5 (1): 38-53.

Berman, R. J., Quinn, C. H., Paavola, J., (2015). Identifying drivers of household coping strategies to multiple climatic hazards in Western Uganda: implications for adapting to future climate change. Climate and Development, 7 (1):71-84.

Berrang-Ford, L., James, D., Ford, J. D., Paterson, J., (2011). Are we adapting to climate change? Global Environmental Change, 21:25-33.

Bisaro, A., Roggero, M. and Villamayor-Tomas, S. (2018). Institutional analysis in climate change adaptation eesearch: A systematic literature review. Ecological Economics, 151:34-43. www.elsevier.com/locate/ecolecon.

Dessai, S., Hulme, M., (2004). Does climate adaptation policy need probabilities? Climate Policy, 4 (2): 107-128.

Dewulf, A. (2013). Contrasting frames in policy debates on climate change adaptation. WIREs Climate Change, (4):321-330. http://dx.doi.org/10.1002/wcc.227. 
Dhungana, H., Pain A., Khatri, D., Gurung, N. and Ojha, H. (2013). Climate Change and Rural Institutions in Nepal. DIIS Working Paper 16. Copenhagen, Denmark: Danish Institute for International Studies (DIIS).

Di Gregorio, M., Nurrochmat, D. R., Paavola, J., Sari, I. M., Fatorelli, L., Pramova, E., Locatelli, B., Brockhaus, M., Kusumadewi, S. D. (2017). Climate policy integration in the land use sector: mitigation: adaptation and sustainable development linkages. Environmental Science Policy, 67:35-43. Available at www.elsevier.com/locate/envsci.

DWIDM (2006). Water induced disaster management policy 2006. Kathmandu: Department of Water Induced Disaster Management.

Ford, J. D., Pearce, T. (2010). What we know, don't know, and need to know about climate change vulnerability in the western Canadian Arctic. Environ. Res. Lett. 5. http://dx. doi.org/10.1088/1748-765 9326/5/1/014008.

Fisher, S., and Slaney, M., (2013). The monitoring and evaluation of climate change in Nepal: a review of national systems. IIED Research Report. London: International Institute for Environment and Development (IIED). Retrieved from http://pubs.iied.org/pdfs/10064IIED.pdf

Geerlings, H., Stead, D. (2003). The integration of land use planning, transport and environment in European policy and research. Transportation Policy, 10:187196. https://doi.org/10.1016/S0967-070X (03)00020-9

HMG (1997). Environment Protection Act, 1997. Kathmandu: HMG

HMG (1993). Forest Act, 1993. Kathmandu: HMG.

HMG (1992). Water Resources Act. Kathmandu Nepal: HMG.

Huq, S., Reid, H., Konate, M., Rahman, A., Sokona, Y., Crick, F. (2004). Mainstreaming adaptation to climate change in least developed countries (LDCs). Climate Policy, 4 (1): 25-43.

IPCC (2014a): Climate change 2014: Synthesis report. Contribution of Working Groups I, II and III to the Fifth Assessment Report of the Intergovernmental Panel on Climate Change [Core Writing Team, R.K. Pachauri and L.A. Meyer (eds.)]. IPCC, Geneva, Switzerland, 151 pp.

IPCC (2014b). Climate change 2014: Impacts, adaptation and vulnerability. Part A: Global and Sectoral Aspects. Working Group II contribution to 5th Assessment 
Report of the Intergovernmental Panel on Climate Change. Cambridge University Press.

IPCC (2001). Climate change: Impacts, adaptation and vulnerability. Summary for Policy Makers. Geneva: World Meteorological Organisation $\square$ http://www.ipcc. ch/ ipccreports/tar/wg2/index.php?Idp=0 $\square$ [Accessed 3 June 2016].

Lamsal, K., Chaudhary, P. and Bhandari, K. H. (2014). Climate Change Policy in Nepal: Challenges, Opportunities and Imperative. Pokhara, Nepal: LI-BIRD.

Levine, S., Ludi, E., Jones, L. (2011). Rethinking Support for Adaptive Capacity to Climate Change. London: Overseas Development Institute (ODI).

Maharjan, S. K. and Maharjan, K. L. (2017). Review of climate policies and roles of institutions in the policy formulation and implementation of adaptation plans and strategies in Nepal. Journal of International Development and Cooperation, 23 (No. 1 \& 2):1-14.

Meyer-Ohlendorf, L. (2009). Climate Change, Vulnerability and Adaptation in SubSaharan African Cities: New Challenges for Development Policy. Research Project on Climate Change and Development, Bonn, Germany: German Development Institute.

MOAC (2011). Climate change adaptation and disaster risk management in agriculture: Priority framework for action 2011-2020. Kathmandu: Ministry of Agriculture and Cooperatives (MOAC). http://www.fao.org/docrep/015/an713e/an713e00. pdf

MoAC (2004). National Agriculture Policy (NAP). Kathmandu: Ministry of Agriculture and Cooperatives. Also available at http://www.moac. gov.np/downloadfile/ Agro_business_policy_2063-8 11_1298620725.pdf

MoE (2011). National framework on local adaptation plans for action (LAPA). Kathmandu: Ministry of Environment (MoE).

MoE (2011). National Climate Change Policy, 2011. Kathmandu: Ministry of Environment (MoE)

MoE (2010). National Adaption Programme of Action (NAPA) to Climate Change. Kathmandu: Government of Nepal, Ministry of Environment (MoE).

MoEST (2012). Climate Change and UNFCCC Negotiation Process. Kathmandu: Ministry of Environment, Science and Technology (MoEST). 
MoFALD (2012). Local Disaster Risk Management Planning Guidelines (LDRMP). Kathmandu: MoFALD.

MoFE (2018). Nepal National REDD+ Strategy. Kathmandu: Ministry of Forest and Environment (MoFE).

MoFE (2018). National Ramsar Strategy and Action Plan, Nepal (2018-2024). Kathmandu: Ministry of Forests and Environment (MoFE).

MoFSC (2016). Forestry Sector Strategy (2016-2025). Kathmandu: Ministry of Forest and Soil Conservation (MoFSC).

MoFSC (2015). Forest Policy 2015. Kathmandu: Ministry of Forest and Soil Conservation (MoFSC).

MoHA (2009). National Strategy for Disaster Risk Management, 2009. Kathmandu: Ministry of Home Affairs.

MoIr (2014). Irrigation Policy, 2014. Kathmandu: Ministry of Irrigation.

MoLJCAPA (2017). Disaster risk reduction and management act 2017. Kathmandu: Ministry of Law, Justice and Parliamentary Affairs.

MoLJPA (2017). Local Government Operation Act 2017. Kathmandu: Ministry of Law, Justice and Parliamentary Affairs.

MoPE (2017). National Adaptation Plan Formulation Process. Kathmandu: Ministry of Population and Environment (MoPE).

MoPE (2017). Synthesis of Stocktaking Report for National Adaptation Plan (NAP). Kathmandu: Ministry of Population and Environment (MoPE).

MoPE (2016). Briefing note on UNFCCC COP 22 and Nepal's Key Concerns, Issues and Events. Kathmandu: Ministry of Population and Environment (MoPE).

MoPE (2012). Mountain environment and climate change in Nepal. National report prepared for the international conference of mountain countries on climate change, 5-6 April 2012. Kathmandu: Ministry of Environment.

MoPE (2004). Initial national communication to the Conference of the Parties of the United Nations Framework Convention on Climate Change. Kathmandu: Ministry of Population and Environment. 
MoSTE (2015). National adaptation plan formulation process. Kathmandu, Nepal: Ministry of Science, Technology and Environment (MoSTE), Climate Change Management Division.

MoSTE (2013). Economic Impact Assessment of Climate Change in Key Sectors in Nepal. Kathmandu: Ministry of Science, Technology and Environment (MoSTE), Government of Nepal, Nepal, retrieved from http://www.asiapacificadapt.net/ sites/default/files/resource/attach/EIAsummary_sharing_final-low-resolution. pdf, on 25 August 2017

MoSTE (2012). Climate Change and UNFCCC Negotiation Process. Kathmandu: Government of Nepal/ Ministry of environment and Science and Technology (GoN/MoEST).

Mubaya, C. P., Mafongoya, P. (2017). The role of institutions in managing local level climate change adaptation in semi-arid Zimbabwe. Climate Risk Management, (16): 93-105. http://dx.doi.org/10.1016/j.crm.2017.03.003.

Nkiaka, Elias and Lovett, Jon C. (2018). Mainstreaming climate adaptation into sectoral policies in Central Africa: Insights from Cameroun. Environmental Science and Policy (89): 49-58. www.elsevier.com/locate/envsci.

NPC (2016). Fourteenth Plan (2016/17-2018/19). Kathmandu: National Planning Commission (NPC).

NPC (2015). Sustainable Development Goals, 2016-2030, National (Preliminary) Report. Government of Nepal, National Planning Commission, Kathmandu, Nepal.

NPC (2013). Thirteenth Plan (2013/14-2015/16). Kathmandu: National Planning Commission.

NPC (2011). Climate-Resilient Planning. Working Document. Kathmandu, Nepal: Government of Nepal, National Planning Commission.

NPC (2010). Twelfth Plan (2010/11-2012/13). Kathmandu: National Planning Commission.

NPC (2007). Three Years Interim Plan (2007-2010). Kathmandu: National Planning Commission.

NPC (2002). Tenth Plan, 2002-2007. Kathmandu: National Planning Commission. 
NPC (1997). The Ninth Plan (1997-2002). Kathmandu: National Planning Commission/ HMG.

NPC/IUCN (2013). Review of National Conservation Strategy (NCS 1988). Volume I. Kathmandu: NPC/IUCN.

Ojha, H. R., Ghimire, S., Pain, A., Nightingale, A., Khatri, D. B. \& Dhungana, H. (2016). Policy without politics: technocratic control of climate change adaptation policy making in Nepal. Climate Policy, 16(4), 415-433.

Osman-Elasha et al. (2006). Adaptation strategies to increase human resilience against climate variability and change: Lessons from the arid regions of Sudan. Assessments of Impacts and Adaptations to Climate Change AIACC Working Paper 42.

Pant, D. \& K. Gautam. (2013). Policy provisions and local response on climate change adaptation in Nepal. Regional Climate Change Adaptation Knowledge Platform for Asia, Partner Report Series No. 12. Stockholm Environment Institute, Bangkok. Available online at www.asiapacificadapt.net or www.weADAPT. org.

Ranabhat, S., Ghate, R., Bhatta, L. D., Agrawal, N. K. and Tankha, S. (2018). Policy coherence and interplay between climate change adaptation policies and the forestry sector in Nepal. Environmental Management. https://doi.org/10.1007/ s00267-018-1027-4.

Regmi, B. R., Shrestha, K. (2018). Policy gaps and institutional arrangements for water resources management in Nepal. HI-AWARE Working Paper 16/2018. Kathmandu: HI-AWARE

Regmi, B. R. \& Star, C. (2015). Exploring the policy environment for mainstreaming community-based adaptation (CBA) in Nepal. International Journal of Climate Change Strategies and Management 7(4): 423-441.

Regmi, B. R., Star, C. and Filho, W. L. (2014) Effectiveness of the local adaptation plan of action to support climate change adaptation in Nepal. Mitigation Adaptation Strategy Global Change, DOI 10.1007/s11027-014-9610-3.

Regmi, B. R. and Bhandari, D. (2013). Climate change adaptation in Nepal: Exploring ways to overcome the barriers. Journal of Forest and Livelihood, 11(1): 43-61. 
Regmi, B. R. and Bhandari, D. (2012). Climate change governance and funding dilemma in Nepal. TMC Academic Journal. 7 (1): 14.

Regmi, B. R. and Karki, G. (2010). Local Adaptation Plans in Nepal. TIEMPO. www. tiempocyberclimate.org

SAARC (2010). Thimpu statement on climate change. Thimpu: SAARC.

SAARC (2008). SAARC Environment Ministers Dhaka Declaration on Climate Change. Dhaka: SAARC.

Saito, N. (2013). Mainstreaming climate change adaptation in least developed countries in South and Southeast Asia. Mitigation and Adaptation Strategies for Global Change, 18(6), 825-849.

Satterthwaite, D., Huq, S., Pelling, M., Reid, H. and Lankao Romero, P. (2007). Adapting to climate change in urban areas: The possibilities and constraints in low-and middle-income countries. IIED Working Paper, London, UK: International Institute for Environment and Development

Scherf, M., Epple, A. \& Werner, T. (2005). The next generation of literature analysis: integration of genomic analysis into text mining. Briefings in bioinformatics, 6(3), 287-297.

Shrestha, A. B., Wake, C. P., Dibb, J. E., and Mayewski, P. A. (1999). Maximum temperature trends in the Himalaya and its vicinity: An analysis based on temperature records from Nepal for the Period 1971-94. Journal of Climate, 12: $2775-2786$.

Thomas, J., McNaught, J. \& Ananiadou, S. (2011). Applications of text mining within systematic reviews. Research Synthesis Methods, 2(1), 1-14.

UN (2002). Report of the World Summit on Sustainable Development. New York: United Nations.

UN (1992). United Nations Framework Convention On Climate Change (UNFCC). New York: United Nation.

UNDP-UNEP (2011). Mainstreaming climate change adaptation into development planning: A guide for practitioners. Nairobi, Kenya: The Poverty-Environment initiative (PEI) of the United Nations Development Programme (UNDP) and the United Nations Environment Programme (UNEP). Available online at www.unpei.org. 
UNISDR, UNDP (2012). Disaster risk reduction and climate change adaptation in the pacific: An institutional and policy analysis. Suva, Fiji: UNISDR, UNDP.

Vij, M., Ahmad, U., Bhadwal, B. (2017). Climate adaptation approaches and key policy characteristics: Cases from South Asia. Environmental Science and Policy,78: 58-65. Available at www.elsevier.com/locate/envsci.

Vij, S., Biesbroek, R. Groot, A. and Termeer, K. (2018). Changing climate policy paradigms in Bangladesh and Nepal. Environmental Science and Policy, 81; 77-85.. Available at www.elsevier.com/locate/envsci.

WECS (2005). National water plan, Nepal. Kathmandu: Water and Energy Commission Secretariat (WECS). Retrieved from http://www.moen.gov.np/pdf_files/ national_water_plan.pdf

WECS (2003). Water Resource Strategy, Nepal. Kathmandu: Water and Energy Commission Secretariat (WECS)

Zougmore et al. (2016). Toward Climate smart-agriculture in West Africa: A review of climate change impacts, adaptation strategies and policy developments for the livestock, fishery and crop production sectors. Agriculture \& Food Security, $5: 26$. 